\title{
Relevance of Health Economics in the Medical Treatment of Breast Cancer: The View of the Professional Association of Practicing Gynecologic Oncologists e.V. (BNGO)
}

\author{
Georg Heinrich $^{\mathrm{a}}$ Hans-Joachim Hindenburg \\ aGynecology/Oncology Focus Practice Fuerstenwalde, \\ ${ }^{\mathrm{b}}$ Gynecology/Oncology Focus Practice Berlin, Germany
}

\section{Keywords}

Adjuvant therapy - Aromatase inhibitors .

Chemotherapy - Systemic therapy - Therapy Costs

\section{Summary}

In this article, the position of the Professional Association of Practicing Gynecologic Oncologists e.V. (BNGO) on the health economics of medical breast cancer therapy is presented. The BNGO unites professionals and employees whose principal activity lies in highly specialized gynecologic oncology. In Germany, 139 specialists are united in 128 professional practices. According to $\S 12$ of the Social Code, the oncological services provided by members must be 'sufficient, effective and economical; they must not exceed what is necessary'. People who are covered by statutory health insurance in Germany are entitled to sufficient benefits. Sufficient measures are measures that benefit the patient with breast cancer and have a positive effect on the course of the disease. In $\S 35 b$ of the Social Code, the benefit of the patient is defined as 'improvement in health, shortening of the duration of illness, lengthening of lifespan, reduction of side effects and an improvement in the quality of life'. In the adjuvant situation, the ideal goal is healing; in the palliative situation, the most basic marker is overall survival, while surrogate markers are the progressionfree interval, improved quality of life, or diminished symptoms. At the same time, the law on economic assessment stipulates 'appropriateness and reasonableness of reimbursement by the insured community'.
Jörg Schilling ${ }^{b}$ Peter Klare ${ }^{b}$

Schlüsselwörter

Adjuvante Therapie · Aromataseinhibitoren .

Chemotherapie $\cdot$ Systemische Therapie $\cdot$ Therapiekosten

\section{Zusammenfassung}

Im vorliegenden Artikel wird der Standpunkt des Berufsverbands der Niedergelassenen Gynäkologischen Onkologen e.V. (BNGO) zur Gesundheitsökonomie der medikamentösen Brustkrebstherapie dargestellt. Der BNGO vereinigt Freiberufler und Angestellte, deren Haupttätigkeit die hochspezialisierte, gynäkologische Onkologie darstellt. In Deutschland sind 139 Spezialisten in 128 Praxen berufspolitisch zusammengeschlossen. Die von den Mitgliedern erbrachten onkologischen Leistungen müssen nach § 12 Sozialgesetzbuch "ausreichend, zweckmäßig und wirtschaftlich sein; sie dürfen das Maß des Notwendigen nicht überschreiten". Gesetzlich Krankenversicherte in Deutschland haben Anspruch auf ausreichende Leistungen. Ausreichend sind Maßnahmen, die bei Brustkrebs einen Patientennutzen erreichen und den Verlauf der Erkrankung positiv beeinflussen. Das Sozialgesetzbuch definiert in $\S 35 \mathrm{~b}$ den Patientennutzen als "Verbesserung des Gesundheitszustandes, eine Verkürzung der Krankheitsdauer, eine Verlängerung der Lebensdauer, eine Verringerung der Nebenwirkungen sowie eine Verbesserung der Lebensqualität». In der adjuvanten Situation ist das Idealziel die Heilung, in der palliativen Situation gilt als härtester Marker das Gesamtüberleben; surrogate Marker sind das progressionsfreie Intervall, eine verbesserte Lebensqualität oder Symptomlinderung. Gleichzeitig schreibt das Gesetz eine wirtschaftliche Bewertung auf «Angemessenheit und Zumutbarkeit einer Kostenübernahme durch die Versichertengemeinschaft" vor.

\section{KARGER \\ Fax +497614520714 \\ Information@Karger.com}

www.karger.com (c) 2013 S. Karger GmbH, Freiburg

$1661-3791 / 13 / 0081-0029 \$ 38.00 / 0$

Accessible online at:

www.karger.com/brc 


\section{Health Economic Relevance of Drug Therapy}

Demographic changes with an aging population and the rising incidence of breast cancer are confronted by increasingly expensive drugs, some with years of patent protection. Annual treatment costs of $€ 30,000-60,000$ per patient represent huge challenges for health insurers [1]. Guaranteeing high quality care in medical breast cancer therapy under these economic framework conditions is a goal of the Professional Association of Practicing Gynecologic Oncologists e.V. (BNGO).

Rising costs of breast cancer treatment can be explained by the following factors:

- increased prevalence of breast cancer,

- improved survival times,

- longer therapeutic duration,

- diversification of therapeutic approaches,

- approval of new medications,

- development of new pharmacogenetic diagnostics, e.g. gene chip analysis.

Breast cancer is by far the most frequent cancer in women [2]. The increase in the disease incidence and improving survival rates have led to a significant increase in prevalence. According to the Robert Koch Institute, the current 5- and 10-year prevalence rates are 250,000 and 416,000 women, respectively. The actual figures are predicted to be considerably higher through the effect of mammography screenings in women of up to 50-69 years.

At the same time, age-standardized mortality has decreased by $5 \%$ in comparison with 1980 . This is caused by improved diagnostics in earlier stages of the disease and more effective therapy. The diversification of therapeutic approaches ('personalized medicine') with sometimes longer duration of treatment and more medications, however, leads to an increase in cost.

An example of a longer duration of therapy is that of antiestrogen therapy. Since 1980, the proportion of patients treated with anti-estrogen drugs has continually increased. This is a result of the demand for stage- and guideline-consistent therapy with a positive hormone receptor status [3, 4], the authorization of aromatase inhibitors, selective estrogen receptor modulators (SERMs) (fulvestrant) and the lengthening of adjuvant treatment duration to up to 10 years. Regarding 3rd-generation aromatase inhibitors (anastozole, letrozole, exemestane), after the termination of patent deadlines there was a drop in medication prices and treatment costs.

A 5-year tamoxifen therapy with a generic product costs $€ 5.84$ per month $=€ 350.40$ in 5 years. In comparison, a 5-year therapy with generic letrozole costs $€ 34.69$ per month $=€ 2081.40$ in 5 years. In the adjuvant situation, according to the present authorization status, with a maximum duration of the anti-hormonal effect through broader, adjuvant therapy during postmenopause ( 5 years of tamoxifen +5 years of letrozole), due to the generic advantage there is a price advantage of $€ 2431.80$. Besides the actual cost of anti-hormone medication, the costs of the treatment of therapy-induced side effects must also be calculated, such as analgetics, bisphosphonate and denosumab. These additional costs are to be reimbursed by statutory health insurers as part of the authorization.

The definition of therapeutic predictors has led to the diversification of therapeutic approaches. The concept of individualized therapy is applicable if necessary for patient groups with defined, predictive biomarkers. In breast cancer, the most important biomarkers are hormone receptors and the human epidermal growth factor receptor 2 (HER2). The use of anti-estrogenic substances and anti-HER2 therapy (trastuzumab, lapatinib) is only indicated according to the relevant stage, and legally permissible and economical in a legal sense in the presence of these biomarkers. Thus far, the anti-HER2 agents pertuzumab and trastuzmab-DM1 (TDM-1) have only been usable in the context of clinical studies, and were not legally eligible for reimbursement. Suitable applications have been made for approval by the Food and Drug Administration (FDA) and the European Medicines Agency (EMA).

Another example of diversified, targeted therapy is everolimus in refractory, advanced, hormone receptor-positive breast cancer. On 21 June 2012, the EMA approved everolimus for the treatment of hormone receptor-positive, HER2negative advanced breast cancer, in combination with exemestane in postmenopausal women without symptomatic visceral metastases at relapse or progression after nonsteroidal aromatase inhibitors. The basis for this is given by the results of the BOLERO-2 study [5]. A total of 724 patients in a 2:1 ratio were prospectively randomized on behalf of a combination of exemestane $(25 \mathrm{mg})$ and everolimus (10 mg) versus exemestane alone. Considered suitable were patients with estrogen receptor (ER)-positive, HER2-non-amplified advanced breast cancer that was refractory to prior therapy with letrozole or anastrozole ( $\leq 12$ months after the end of adjuvant therapy or $\leq 1$ month after the end of palliative therapy). The primary endpoint was progression-free survival (PFS), and secondary endpoints were overall survival (OS), overall response rate (ORR), clinical benefit rate (CBR), and quality of life. For the combination of exemestane-everolimus, a PFS of 6.9 months was determined, versus 2.8 months for the combination exemestane-placebo. The hazard ratio regarding PFS or death was 0.43 in favor of exemestane-everolimus $(95 \%$ confidence interval (CI) $0.35-0.54, \mathrm{p}<0.001$ ).

This therapeutic situation now represents monthly treatment costs of $€ 39.15$ (monotherapy: generic exemestane) versus $€ 39.15+€ 4530.35$ (generic exemestane + everolimus), a cost increase by a factor of 117 . The use of everolimus in clinical routine continued to be studied in the phase IV trials '4Ever' and 'BRAWO' in clinical practice.

In the development of new pharmacogenetic diagnostics (gene chip analyses), their clinical usefulness has to be measured as well. This still requires a considerable degree of study activity before the procedure can be used widely as obligatory 
examination procedure. In the group of luminal A tumors (ER/progesterone receptor (PR) positive, HER2 negative), the use of additional chemotherapy to prevent recurrence could not be demonstrated conventionally. Knowing that the majority in this patient group received overtreatment, for reasons of maximum certainty chemotherapy was indicated (tertiary prevention). Nonetheless, the willingness to use, for example, the OncotypeDX ${ }^{\circledR}$ test (Genomic Health, Inc.) as a broad diagnostic tool for making a decision for or against chemotherapy is clearly less prevalent in Europe than in the USA. Unambiguous studies that clearly demonstrate superiority of this test compared to the 'classic' prognostic factors are not yet available. Additionally, the centralized implementation of this test in California with a delayed test result makes European insurers less rapidly willing to reimburse it. In its current guidelines, the working group 'Mamma' of the Association of Gynecological Oncology (AGO) only recommends gene/protein testing in the context of studies [3].

The development of the EndoPredict ${ }^{\circledR}$ (EP) test (Sividon Diagnostics $\mathrm{GmbH}$ ) may be viewed as an example of diagnostic effectivity improvement $[6,7]$. In this decentralized test, molecular genetic analyses (8 tumor-associated genes and 3 reference genes from the formalin-fixed paraffin-embedded (FFPE) specimen) are combined with the classic prognostic markers (tumor size and nodal status), to offer a scientific basis in the adjuvant situation for patients with hormone receptor-positive, HER2-negative breast cancer (luminal tumors) for anti-hormone therapy alone or additional chemotherapy. In 2 prospectively randomized, translational studies (ABCSG-6: tamoxifen 5 years with vs. without aminogluthetimide 2 years, $\mathrm{n}=378$; ABCSG-8: tamoxifen vs. tamoxifen 2 years, followed by anastrozole 3 years, $n=1324$ ) with the above-described test, a recurrence score based only on molecular testing (EP score) was compared with a combination of tumor size and nodal status (EPclin score). The median follow-up was 97.4 (ABCSG-6) and 72.3 (ABCSG-8) months. All patients had luminal tumors with a low risk of metastasis. This retrospective analysis shows that molecular testing combined with the tumor size and the lymph node involvement can be a tool to predict low and high risk of recurrence in this group (fig. 1). EPclin groups are much more linked to recurrence risk than the clinical markers alone.

With the aid of EPclin scores, the patient could be spared both unnecessary toxicity and unnecessary expenses through chemotherapy.

The calculated costs for implementing EndoPredict testing consist of individual health service according to the fee schedule for medical services (GOÄ) and the material costs of the test, equaling approximately $€ 1820$. For adjuvant standard chemotherapy, for example with the $\mathrm{FEC}_{100}-\mathrm{Doc}_{100}$ scheme (epirubicin $100 \mathrm{mg} / \mathrm{m}^{2}$ with 5-fluorouracil $500 \mathrm{mg} / \mathrm{m}^{2}$ and cyclophosphamide $500 \mathrm{mg} / \mathrm{m}^{2}$ plus docetaxel $100 \mathrm{mg} / \mathrm{m}^{2}$ ) for a $75-\mathrm{kg}$ patient, approximately $€ 9000$ was calculated. In addition to unnecessary toxicity, these costs could also be

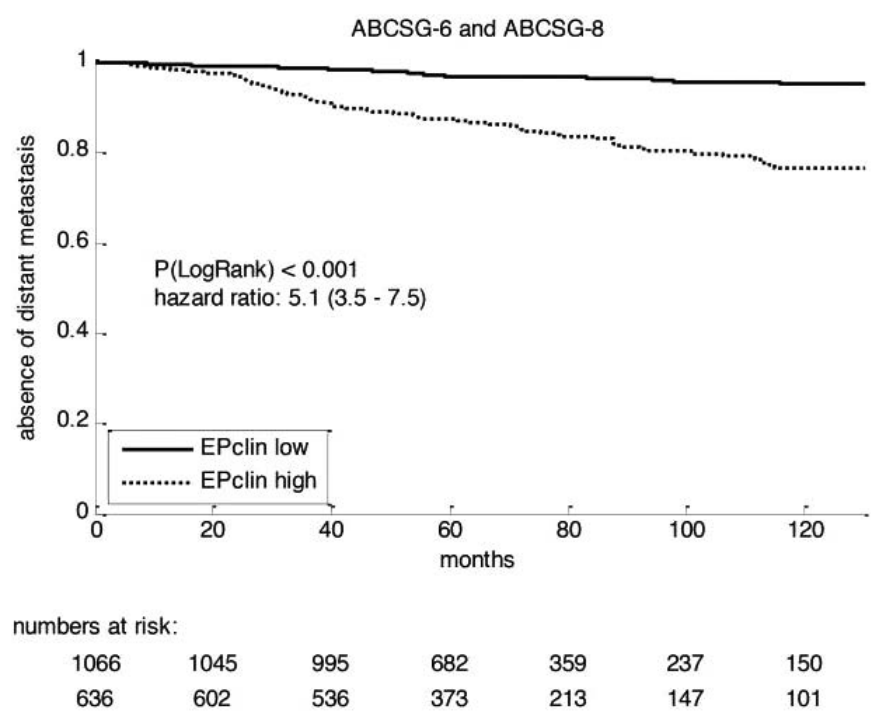

Fig. 1. Kaplan-Meier plots for distant disease-free survival of patients in EPclin high-risk (black line) and EPclin low-risk groups of the ABCSG-6 and ABCSG-8 trials. Adapted from Dubsky et al. [8].

considerably reduced with a risk assessment using the EP test. Further systematic studies, including those in the framework of health services research, are necessary here.

Therapy costs at the end of life are caused primarily by inpatient treatment [9]. In an American review of the Life Science Research Database, in 28,530 patients (cancer of the lung, breast, prostate, uterus, cervix, ovary, and bladder, colorectal cancer, lymphoma, leukemia, etc.), the respective costs for inpatient and outpatient treatment in the last 6 months of life were evaluated. While the monthly costs of inpatient treatment increased from 12.2 to $43.8 \%$, over the same period the outpatient costs decreased (chemotherapy, supportive therapy), dropping continuously from 44.6 to $24.0 \%$. The authors call for stage-appropriate information for the patient and the timely implementation of a palliative concept at the end of life. This is associated with more hospice care, less intensive medical measures and better quality of life at the end of life.

\section{National Cancer Plan - Where Does the BNGO Stand?}

The 'National Cancer Plan' (2008) initiated by the Federal Ministry of Health in cooperation with the German Cancer Society, the German Cancer Aid, and the Association of Tumor Centers contains defined goal formulations for the improvement of oncological care [10]. These 13 target formulations are divided into 4 areas of action. Here, a center is defined as a "network of qualified and jointly certified, multiand interdisciplinary, cross-sectoral and possibly multi-site facilities (hospitals, statutory medical care, rehabilitation facilities) that delineate the entire care chain for patients as far as this is professionally available'. In goal 4 , an extensive 
application of 'care models exemplary and proven for broad care' is formulated. The active participation of BNGO members in networks and breast and cancer centers, such as participation in interdisciplinary tumor conferences, has proven itself as an exemplary care model in agglomerations and zones. There is a demand for uniform concepts for quality assurance and promotion according to goal 5. In the view of the BNGO, for example, the minimum requirement according to the standards of professional physicians in medical oncology lies in specialized medical care. 'All patients receive fair and rapid access to demonstrably effective innovative cancer therapies' (goal 10). Patients are enabled to access innovative therapeutic options through participation in clinical trials and health services research in institutions of the BNGO. Among other things, participation in scientific studies is a requirement of health insurance companies and the National Association of Statutory Health Insurance Physicians in the 'oncology agreement' (see below).

The AGO established a group called 'cooperative structures' in 2012 [11]. It forms a consensus for cooperation between gynecologists working on both an inpatient and outpatient basis who participate in the care of breast cancer patients in Germany. The objective is to preserve the proven structures in prevention, care and continued education. The BNGO is actively involved in consensus finding and the refinement of the oncological cooperation in the network. The following are defined as professional partners in this network: (1) gynecology practices, (2) gynecology/oncology focus practices, (3) hospitals with specialists including 'gynecologic oncologists', with and without outpatient sections, and (4) hospitals without specialists, including a subsection 'gynecologic oncology'. Medical tumor therapy is to take place, if possible, on an outpatient basis in the gynecological/oncological focus practice or in the hospital as per (3). If no gynecological/ oncological care is possible, general internal medicine-oncological cotreatment is to be considered.

\section{The 'Oncology Agreement'}

The medical care of breast cancer patients by gynecologists is unique in Europe. Through the historically developed structures and the implementation of high oncologic standards through the continued education in 'gynecologic oncology' and the additional development of 'medical tumor therapy' in gynecology by medical associations, gynecologists have assumed a high degree of responsibility in oncologic care. For outpatient services in the context of statutory medical insurance, in 2009 the new 'oncology agreement' was concluded between the leading association of statutory medical insurers and the national health services association (German Medical Association) [12]. The technical requirements for the admission of physicians to outpatient oncology are specified in appendix 3 to the oncology agreement as per $\S 3$ paragraph 7 .
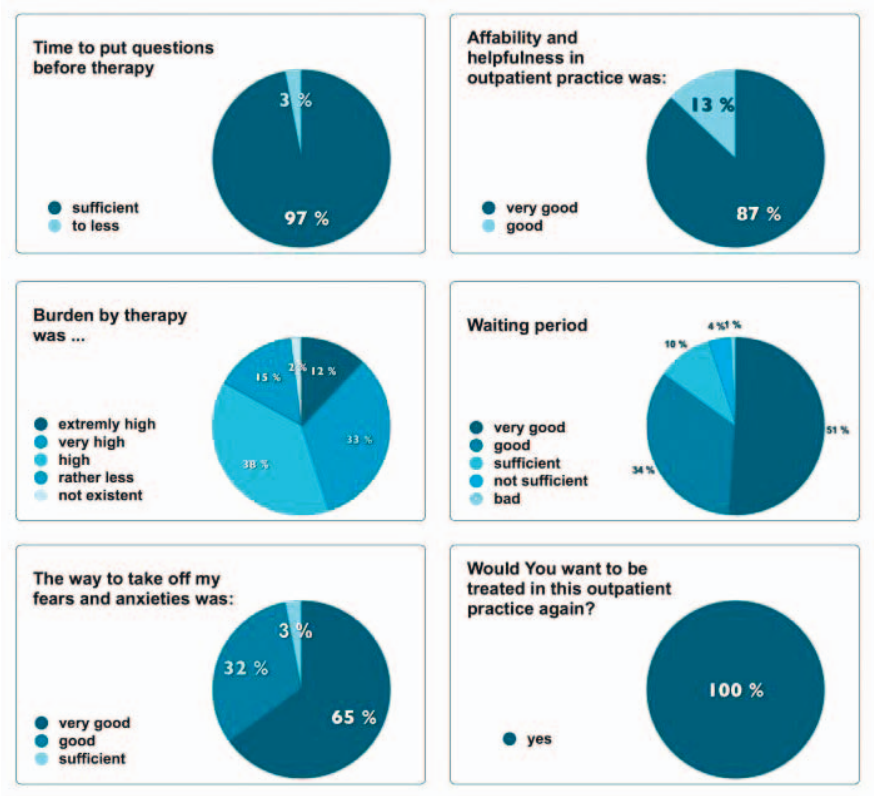

Fig. 2. Patient satisfaction in outpatient practice, results of a systematic evaluation, BNGO 2012 [13].

However, apart from technical expertise, an economic perspective is also essential to rational medical therapy. The decisions in breast centers should be based on the guidelines [ 3 , 4]. In addition to purely evidence-based, guideline-oriented medicine, in everyday medical practice the individual patient situation and regulatory provisions must also be considered. Deviation of medical therapy from the current guidelines or from the text of authorization requires meticulous substantiation and can lead, in an extreme case, to compensation claims for health insurers. This also relates to recommendations that are given in interdisciplinary tumor committees in breast centers. Here, BNGO members can introduce the legal status quo at interdisciplinary tumor committees and thus contribute to rational medical therapy. In individual cases, drug therapy can also deviate from authorization (off-label use). In social court proceedings, exculpatory grounds for deviation from authorization are formulated: life-threatening disease, the presence of overt study data, and the absence of an equivalent alternative.

\section{Health Services Research}

In addition to classical drug trials, a new scientific field of work is gaining significance: health services research [13]. This represents a link between clinical research and medical practice. The German Medical Association defines health services research as 'the scientific study of the care of individuals and populations with health-related products and services in everyday life'.

The aim of health services research is the establishment of need, quality, and improvement possibilities with regard to 
medical services in everyday life. The BNGO implemented a nationwide assessment of medical care in Germany, also with regard to compliance to $\S 12$ of the Social Code [14]. In 128 outpatient facilities with a total of 139 doctors, medical care in oncology was observed and evaluated. In addition, the BNGO carried out a systemic evaluation of patient satisfaction in the outpatient area [13] (fig. 2). 1743 patients in 125 practices were interviewed from January to June 2011 using a standardized questionnaire with 18 questions about the practice situation and treatment. $50 \%$ of the respondents were receiving chemotherapy at the time of the survey, $11 \%$ anti-hormonal therapy, $8 \%$ other infusion therapy, and 3\% antibody therapy. The majority of the patients interviewed were quite satisfied with the work and the quality of gyneco-oncologic practices. All the patients interviewed would go through treatment in the practice again. The results were presented at the Senology Congress in Stuttgart (Germany) in 2012 and, among 22 submissions, honored with the Health Services Research prize of the Senology Association.

\section{Conclusions}

The current demographic developments, the increasing prevalence of breast cancer, and limited financial resources force us to use economical therapy in all sectors of our health care system, in addition to evidence-based therapy. The BNGO with its members works exclusively in the outpatient sector. As gynecological oncologists, we are obliged to rational medical therapy in which the patient's well-being is the focus. Neither unreflective medicine oriented to sales nor maximum technical expense or a superficial scaling down (the physician as savings agent in third-party contracts) is supported by the professional association. Work in the oncological network in the sense of comprehensive, specialized professional medical care continues to be promoted by the BNGO.

\section{Disclosure Statement}

The author declares no conflict of interests.

\section{References}

1 Glaeske G: Sicherstellung einer effizienten Arzneimittelversorgung in der Onkologie. Gutachten im Auftrag des Bundesministeriums für Gesundheit. Bremen, 2010. http://bmg.bund.de/fileadmin redaktion/pdf_allgemein/Gutachten_Sicherstellung_ einer_effizienten_Arzneimittelversorgung_in_der_ Onkologie.pdf.

2 Robert Koch-Institut (Hrsg): Verbreitung von Krebserkrankungen in Deutschland. Entwicklung der Prävalenzen zwischen 1990 und 2010. Beiträge zur Gesundheitsberichterstattung des Bundes. Berlin, RKI, 2010. http://bmg.bund.de/fileadmin/ dateien/downloads/K/Krebs/Nationaler_Krebsplan/ Krebspraevalenz.pdf.

3 AGO: Diagnostik und Therapie primärer und metastasierter Mammakarzinome. AGO e.V. in der DGGG e.V. sowie in der DKG e.V. Guidelines Breast Version 2012.1D. http://ago-online.de/ fileadmin/downloads/leitlinien/mamma/ oktober2012/pdf/AGO_Version_2012_D.pdf.

4 Interdisziplinäre S3-Leitlinie für die Diagnostik, Therapie und Nachsorge des Mammakarzinoms. Langversion 3.0, Aktualisierung 2012, AWMF-RegisterNummer: 032 - 045OL. http://krebsgesellschaft.de download/S3_Brustkrebs_Update_2012_OL_ Langversion.pdf.
5 Baselga J, Campone N, Piccart M, Burris HA, Rugo HS, Sahmoud T, Noguchi S, Gnant M, Pritchard KI, Lebrun F, Beck T, Ito Y, Yardley D, Deleu I, Perez A, Bachelot T, Vittori L, Xu Z, Mukhopadhyay P, Lebwohl D, Hortobagyi: Everolimus in postmenopausal hormone-receptor-positive advanced breast cancer. N Engl J Med 2012;366: 520-529.

6 Filipits M, Rudas M, Jakesz R, Dubsky P, Fitz F, Singer CF, Dietze O, Greil R, Jelen A, Sevelda P, Freibauer C, Mueller V, Jaenicke F, Schmidt M, Koelbl H, Rody A, Kaufmann M, Schroth S, Brauch H, Schwab M, Fritz P, Weber KE, Feder IS, Hennig G, Kronenwett R, Gehrmann M, Gnant M: A new molecular predictor of distant recurrence in ER-positive, HER2-negative breast cancer adds independent information to conventional clinical risk factors. Clin Cancer Res 2011;7:6012-6020.

7 Dietel M, Kronenwett R, Schlake W, Bohmann K, Penzel R, Weber KE, Höfler H, Lehmann U, Schirmacher P, Specht K, Rudas M, Kreipe HH, Schraml P, Schlake G, Bago-Horvath Z, Tiecke F, Moch H, Schmidt M, Prinzlern J, Kerjaschki D, Sinn B, Filipits M, Petry C, Denkert C: Das ERpositive, HER2-negative Mammakarzinom - Der EndoPredict ${ }^{\circledR}$-Test hilft bei der Entscheidung über die endokrine Therapie +/- Zytostase. Senologie 2012;8:6-9.
8 Chastek BJ, Harley C, Kallich K, Newcomer L, Paoli CJ, Teitelbaum AH: Health care costs for patients with cancer at the end of life. J Oncol Pract 2012;8:75-80.

9 http://bmg.bund.de/praevention/nationaler-krebsplan/ handlungsfelder/ziele-des-nationalen-krebsplans. html.

10 Runnebaum IB: Strukturen in der gynäkologischen Onkologie. Konzeptpapier der AGO-Arbeitsgruppe Kooperationsstrukturen. Frauenarzt 2012;53:290-293.

11 Vereinbarung über die qualifizierte ambulante Versorgung krebskranker Patienten 'OnkologieVereinbarung' (Anlage 7 zu den Bundesmantelverträgen zwischen GKV-Spitzenverband K.d.ö.R., Berlin, und der Kassenärztlichen Bundesvereinigung, K.d.ö.R., Berlin). Berlin, 2011. http://kbv.de/ rechtsquellen/2297.html.

12 Rahmenkonzept zur Förderung der Versorgungsforschung. Berlin, Bundesärztekammer, 2005. http://bundesaerztekammer.de/page.asp? his $=0.6$.

13 Hindenburg H-J, et al.: Patientinnenzufriedenheit in gynäko-onkologischen Praxen - eine Umfrage des BNGO. Senologiekongress Stuttgart 2012.

14 Sozialgesetzbuch (SGB) Fünftes Buch (V) - Gesetzliche Krankenversicherung, Artikel 1 des Gesetzes vom 20. Dezember 1988, BGBl. I S. 2477. http://gesetze-im-internet.de/sgb5/. 